\title{
Engineering geological evaluation of some rocks from Akure, Southwestern Nigeria as aggregates for concrete and pavement construction
}

\author{
Omowumi Ademila \\ Adekunle Ajasin University, Department of Earth Sciences; Akungba-Akoko, Nigeria; e-mail: omowumi.ademila@aaua.edu.ng \\ (C) 2019 Authors. This is an open access publication, which can be used, distributed and reproduced in any medium according \\ to the Creative Commons CC-BY 4.0 License requiring that the original work has been properly cited.
}

Received: 17 October 2018; accepted: 13 February 2019; first published online: 11 March 2019

\begin{abstract}
The importance of rocks and rock aggregates cannot be overemphasized in construction and concrete design globally. This study evaluated the physical and mechanical characteristics of fine grained granite, porphyritic granite, quartzite, granite gneiss, migmatite gneiss and charnockite from ten different locations in Akure for their suitability as construction materials. Field observation, water absorption, specific gravity, shape indices, aggregate impact value (AIV), aggregate crushing value (ACV), Los Angeles abrasion value (LAAV), compressive strength, tensile strength and petrography of the selected rocks were evaluated. The field studies indicate fresh outcrops with little signs of weathering. Porphyritic granite shows a higher water absorption value $>1 \%$, suggestive of its unsuitability as foundation materials in water logged areas. The higher flakiness and elongation indices of porphyritic granite, quartzite and migmatite gneiss are detrimental to the higher workability and stability of mixes. AIV (14.79-23.52\%), ACV (18.32-28.93\%) and LAAV (25.22-34.55\%) showed that granite, granite gneiss and charnockite have good soundness and hardness with greater resistance to wear. Higher strength values of all the rocks were found to be satisfactory for use in the production of aggregates for civil constructions. Petrographic analysis revealed similarities in the compositions of the rocks, with quartz being the dominant mineral. The results show that all the rock types possess the required quality standards for use as construction aggregates in highway pavements and foundations. Some of the aggregates (GG1, GG2, GF, GC, MG1, CK1 and CK2) are also suitable for bituminous mixes. Quartzite should be avoided in load bearing masonry units due to its lower strength values. The most suitable rocks proven as road and building stones are fine grained granite, granite gneiss and charnockite because of their low water absorption, low flakiness and elongation indices, low abrasion values, higher strength values (tensile strength and unconfined compressive strength) and sound petrographic characters. Thus, adequate knowledge of rocks and rock aggregates is crucial in order to prevent continuous structural failure around the globe and make the environment friendlier.
\end{abstract}

Keywords: rock aggregates, physical and mechanical characteristics, petrography, concrete, road and building stones

\section{INTRODUCTION}

Construction aggregates are important raw materials for the development of nations. They are essential for constructing and maintaining the physical framework of the buildings and infrastructure on which our societies depend (BGS 2013). Globally, rocks and rock aggregates are one of the important sources of construction materials. A construction aggregate is normally defined as being a hard, granular material which is suitable for use either on its own or with the addition of cement, lime or a bituminous binder in construction. Aggregates, when bound together into a conglomerated mass by cement and water, form 
concrete or mortar. They are also used as wearing surfaces and binders in flexible pavements (highways and runways).

Aggregates may be regarded as coarse (with a size greater than $5 \mathrm{~mm}$ ), fine (a size less than $5 \mathrm{~mm}$ ), and all-in-varieties (comprising both fine and coarse aggregates) (Dhir \& Jackson 1980). Aggregates may also be classified in terms of natural aggregate (from mineral sources with only physical processing, often referred as 'primary aggregate'), manufactured aggregate (derived from industrial processes as a by-product, often referred to as 'secondary aggregate') and recycled aggregate (recovered from material previously used in construction) (BGS, 2013). The suitability of naturally occurring rocks for the production of construction aggregate relies on their testing according to national and international standards. Construction aggregate broadly comes in two main categories; hard rock aggregates which are typically sourced from igneous rocks such as granite, dolerite and gabbro, sedimentary rocks such as sandstone and limestone, and metamorphic rocks such as gneiss and marble. These are extracted in quarries by drilling, blasting and crushing. Built-in aggregates should produce the desired properties in both fresh and hardened concrete (Jackson 1984). Sand and gravel aggregate is typically sourced from unconsolidated sediments of fluvial, lacustrine or marine origin. These are extracted in quarries by mechanical excavators. Both types of aggregates are washed and screened to create the required construction aggregate products (Mitchell 2007).

Rocks have usually been quarried for some time without the knowledge of their engineering properties before they are used for civil engineering construction. Rocks used as construction materials need to meet high quality standards in order to ensure the best behaviour in all situations (Siegesmund \& Torok 2011). The physical properties of the rocks are the results of their mineralogical composition and fabric, their geological, environmental and deformational history including the alteration and weathering processes (Vallejo \& Ferrer 2011). Different conditions have to be considered to determine whether a rock is suitable or not as aggregate for road pavement construction. Aggregates generally occupy $70-80 \%$ volume of concrete and can therefore be expected to have important influences on their properties (Fowler \& Quiroga 2003) which provide good dimensional stability and wear resistance for concretes. Aggregates used for construction purposes must be strong and durable. Smith \& Collis (1993) identified the main factors influencing aggregates behaviour in various operational and environmental conditions and concluded that the performance of aggregates depends upon their intrinsic properties like particle shape, grading, composition and its physical and chemical properties. The petrographic characteristics of rocks are very important for rock behaviour. The petrographic characteristics must be correctly known to understand the performance of the rocks to be used as dimension stone during the time spent under specific environmental conditions and to avoid inaccurate applications (Sousa 2012). Natural aggregate particles are originally formed as part of a larger parent mass, which may have been fragmented by natural processes of weathering and abrasion or artificially by crushing. Hence, many properties of the aggregate depend entirely on the properties of the parent rock. For the ease of quarrying and accessibility, rocks must satisfy the requirements of strength, workability, hardness, durability, porosity and appearance (Eren \& Bahali 2005).

Despite the abundant basement rocks in the southwestern part of Nigeria, little or no data exist on the properties of rocks suitable as construction aggregate. This study investigates the physical and mechanical properties and petrographic characteristics of some rocks for their suitability as construction aggregates for concrete and building structural pavements.

\section{LOCATION AND GEOLOGY OF THE AREA OF STUDY}

Akure, the capital of Ondo State, Nigeria is bounded by latitudes $7^{\circ} 13^{\prime} \mathrm{N}$ and $7^{\circ} 19^{\prime} \mathrm{N}$ and longitudes $5^{\circ} 07^{\prime} \mathrm{E}$ and $5^{\circ} 14^{\prime} \mathrm{E}$ (Fig. 1). The area is flanked to the north by Ikere and Akure North local government areas, Owo to the east, Ile-Oluji/Oke-Igbo local government area to the west and to the south by Idanre local government area. It is geographically located within the sub-equatorial climatic belt of tropical rainforest vegetation with evergreen and broad-leaved trees. 


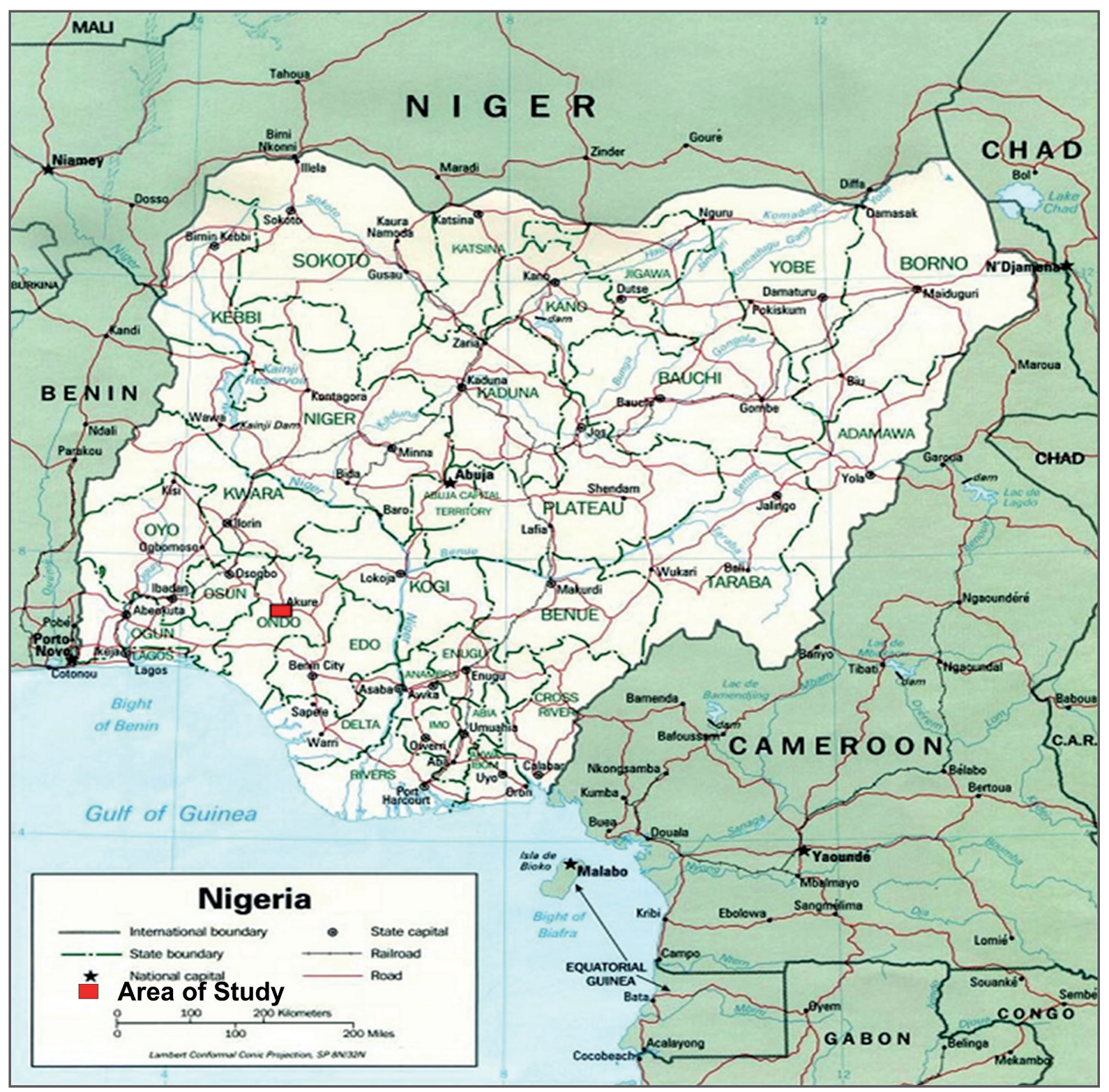

Fig. 1. Map of Nigeria showing the area of study

It is characterized by alternating wet and dry seasons, fairly uniform temperature, heavy and well distributed rainfall throughout the year with relatively high humidity. The mean annual temperature is about $22^{\circ} \mathrm{C}$ during harmattan (December to February) and $32^{\circ} \mathrm{C}$ in March while the rainfall peaks twice in July and September and varies between $1,500 \mathrm{~mm}$ and $3,500 \mathrm{~mm}$ per year. The rainfall decreases in amount and distribution from the coast to the hinterland.

The study area falls within the Basement Complex of Southwestern Nigeria (Fig. 2). The Basement Complex rocks of Nigeria forms a part of the African Crystalline Shield which occurs within the Pan-African Mobile Belt that lies between the West African and Congo Cratons and South of the Tuareg Shield which were affected by the Pan-African Orogeny. The Southwestern basement is within the triangular part of the Nigerian basement, an extension of the Dahomeyide Shield of the West African Craton. Rocks of the region include Migmatized-Gneiss Complex (MGC) that is characterized by (a) grey foliated gneiss, (b) ultramafic rocks and (c) felsic component comprised of pegmatite, aplite and granitic rocks (Rahaman 1981). 


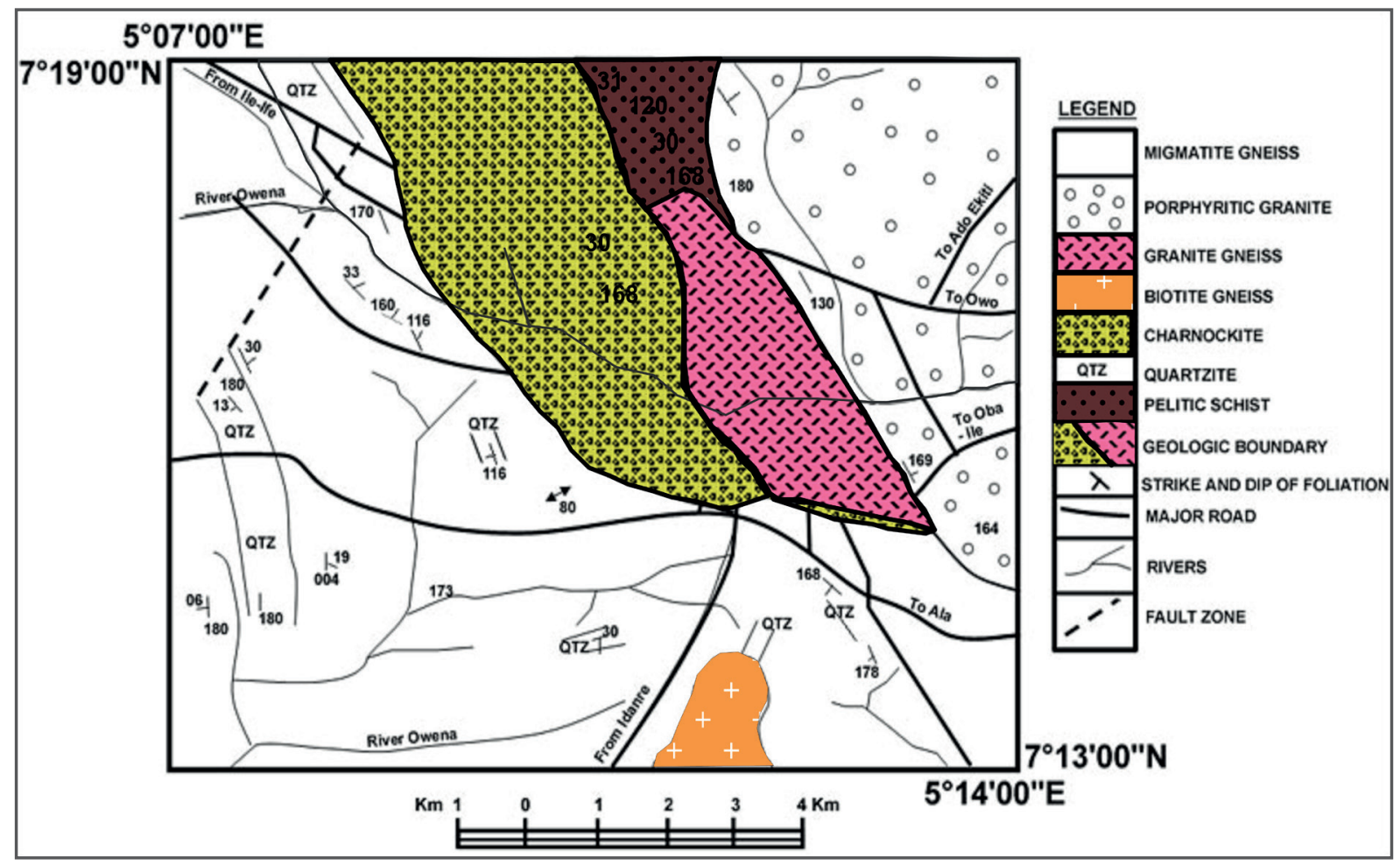

Fig. 2. Geologic map of the area of study (modified after Olorunfemi et al. 1999)

The MGC in Southwestern Nigeria is affected by three major geotectonic events ranging from Early Proterozoic of 2000 Ma to Pan-African events of $\sim 600 \mathrm{Ma}$ (Ajibade \& Fitches 1988, Oyinloye 2011). The rocks of the basement have been affected by medium pressure Barrovian metamorphism (Rahaman et al. 1983, Oyinloye 2011). They are located in a gently undulating terrain surrounded by inselbergs, underlain by granites, charnockites, quartzites, granite gneisses and migmatite gneisses (Olarewaju 1981). The area is drained by the River Ala, River Owena, River Ogburugburu and their major tributaries with a dendritic drainage pattern.

\section{MATERIALS AND METHODS}

This research includes detailed geological field mapping to ascertain the local geology of the area. At each location, rock outcrops were carefully examined and described. At the end of the geological field mapping exercises, ten rock samples (two samples from every rock type) were taken from ten different locations of the area of study with the aid of sledge hammer for physical and mechanical tests. Rock types used for this study included granite (fine grained granite and porphyritic granite), charnockites, quartzites, granite gneiss and migmatite gneiss. These rock types were selected and analyzed because of their abundance and ease of sampling. About $30 \mathrm{~kg}$ of aggregate samples each from ten different locations were collected for the laboratory analysis. The properties used to assess the suitability of rocks as aggregate materials include the following tests: water absorption capacity, strength, abrasion resistance, shape indices (flakiness and elongation), resistance to weathering. Laboratory studies of the strength of the aggregates were assessed by means of the following tests: aggregate impact value (AIV), aggregate crushing value (ACV), aggregate abrasion value determined by using the Los Angeles machine (Los Angeles abrasion value - LAAV), specific gravity and water absorption in accordance with BS 882 (1992) and AASHTO (2001). The point load strength index was determined following ASTM D5731-02 (2008). Two tests were made for each test method and the average values were 
used to assess the suitability of the rocks as aggregate materials. Petrographic analysis of the representative rocks was carried out by thin sectioning and examination of the slides under a plane and cross polarized light for the study of the mineralogical composition.

\section{PHYSICAL PROPERTIES OF THE AGGREGATES}

\section{Shape indices}

Hard, tough or brittle rocks will often generate more flakes, whereas softer rocks produce more fines (Mitchell 2007). Shape indices like flakiness index and elongation index were determined. The flakiness index (FI) was calculated by using the equation in accordance with BS 812105.1 (1989):

Flakiness Index $=w / W \times 100$

where $w$ is the weight of the material passing the various thickness gauges and $W$ is the total weight of the aggregate passing and retained on the specified sieves.

Similarly, the Elongation Index was calculated by using the equation in accordance with BS 812 105.2 (1990):

Elongation Index $=m / M \times 100$

where $m$ is the weight of materials retained on specified gauges and $M$ is the total weight of the aggregate passing and retained on the specified sieves.

\section{Water absorption (WA)}

Water absorption value defines the capacity of a rock to absorb moisture when immersed in water. The water absorption of the aggregates controls the amount of the binder required in highway surfacing design (high water absorption value will need more binder materials after the constituents have been mixed). Water absorption value of $0-3 \%$ is allowed for aggregates used in road surfacing or in road constructions (BS 882, 1992). Water absorption test was carried out after AASHTO M-132 (1987). Samples were immersed in water for 24 hours to fill the pores, surface dried and weighedin air and then oven-dried and weighed in air again. The water absorption was calculated as percent absorption relative to dry weight as:

$\mathrm{WA}=\left[\left(W_{2}-W_{1}\right) / W_{1}\right] \times 100 \%$,

where $W_{1}$ is the weight of oven dried sample and $W_{2}$ is the weight of the surface dry saturated sample. A strong aggregate will have a very low absorption value that is below $1 \%$. The amount of water an aggregate can absorb affects the water-cement ratio and the aggregate proportioning which influences the weight of the aggregate (Egesi \& Tse 2012). When the samples are submerged in water under a vacuum, almost all of the air is replaced by water, while in the water absorption test (at normal pressure), some voids remain unfilled, avoiding water penetration.

\section{Specific gravity}

The specific gravity (relative density) of an aggregate is the ratio of its weight to the weight of an equal volume of water. Specific gravity is a reflection of the densities of constituent materials in each sample, excluding the permeable voids they may contain. The ratio of the density of the particles to the density of the water was determined in accordance with ASTM C127-01 (2001). It is very important in the evaluation and identification of aggregates used for engineering construction because a specific gravity value can easily be correlated with the mechanical strength of such materials. The specific gravity was measured by soaking the samples in distilled water for 24 hours and weighing in air after this period. After this, samples were dried and weighed in air, then reweighed in air after oven-drying for 24 hours.

\section{Strength of aggregate}

\section{Aggregate crushing value (ACV) determination}

The aggregate crushing value is a value which indicates the ability of an aggregate to resist crushing under a gradually applied compressive load (a California bearing ratio (CBR) machine or concrete crushing apparatus) over a period of $10 \mathrm{~min}$ utes, after passing through a $14.0 \mathrm{~mm}$ sieve, and retained on a $10.0 \mathrm{~mm}$ sieve. That is, ACV provides the relative measure of resistance to crushing under the gradually applied compressive load. Aggregate crushing value (ACV) and Aggregate 
impact value (AIV) were determined using a compression testing machine and $14 \mathrm{~kg}$ weight hammer respectively following (BS 812, 1990). ACV was calculated using the equation:

$\mathrm{ACV}=M_{2} / M_{1} \times 100$,

where $M_{1}$ is the initial weight of the aggregate sample, $M_{2}$ is the weight of sample passing through sieve with the opening of 8 or $2.36 \mathrm{~mm}$. After compression, the fine materials produced, expressed as a percentage of the original mass is the aggregate crushing value. Materials with low aggregate crushing values are generally preferred to be used in highway pavements (Kadiyali 1989). Aggregates with valueless than $10 \%$ are considered very strong, values between $10-20 \%$ are considered strong and values between $20-30 \%$ are just good enough for roadstone (Singh 1991). Crushing value of 30\% and above is unsuitable for road construction.

\section{Aggregate impact value (AIV) determination}

The impact value of aggregates measures the toughness of particles by impact. AIV is the resistance of the stones to fracture under repeated impact. Impact from traffic movement tends to break aggregate into smaller pieces due to irregularities in road surfaces. Thus, aggregates intended for use in construction should be tough enough to resist friction from such impacts. Aggregate impact value of roadstones is therefore another way to evaluate the strength of the aggregates to be used in road construction. AIV is the percentage of fines produced from an aggregate sample after subjecting it to a standard amount of impact. AIV was calculated using the equation:

$\mathrm{AIV}=W_{2} / W_{1} \times 100$,

where $W_{1}$ is the total weight of the aggregate samples and $W_{2}$ is the weight of aggregated fraction passing through 8 or $2.36 \mathrm{~mm}$ sieve. An aggregate impact value above $35 \%$ would normally be regarded as too weak for use in road surfaces.

\section{Aggregate abrasion value (AAV) determination}

Abrasion tests of aggregates measure the resistance of aggregates to wearing. It is an important property of concrete in roads and in floor surfaces subjected to heavy traffic. The most frequently used test method is the Los Angeles abrasion test. Los Angeles abrasion tests were made following ASTM C131-01 (2001) to obtain mechanical soundness or hardness against abrasion of an aggregate. Rock materials with aggregate abrasion values below $30 \%$ are regarded as strong, while those above $35 \%$ would normally be regarded as too weak for use in road surfaces. This implies that roadstones with lower Los Angeles values will have greater resistance to wear:

\section{LAAV (Los Angeles abrasion value $)=$} $=\left(W_{1}-W_{2}\right) / W_{1} \times 100$.

This indicates the percentage wear, where $W_{1}$ is the original weight of the aggregate sample, $W_{2}$ is the weight of aggregate sample retained and $W_{1}-W_{2}$ is the weight passing through a $1.7 \mathrm{~mm}$ sieve.

\section{Unconfined compressive strength (UCS)}

Strength is an important property influencing the mechanical quality of building stones. Unconfined compressive strength (UCS) of intact rock is the main parameter used in almost all engineering projects (Zorlu et al. 2008). It is an important parameter which is required and determined for mechanical studies in most civil and mining works. Higher tensile strength is needed for the rocks when they are used as facing stones (Bell 2007: 278-288). Higher tensile strength is required to resist environmental stresses like strong wind action causing suction on the outer masonry, vibrations and warping of stone from insufficiently sized slabs (Franklin \& Young 2000). UCS test was conducted in accordance with the conditions given in ASTM C170 (2001). UCS test is certainly the most reliable means to determine the compressive strength of rocks (Liang et al. 2015).

\section{Point load strength test}

The point load strength test (PLST) is an index test for the classification of rock materials on the basis of strength. The point load test involves compressing a rock sample between conical steel platens until failure occurs. It was carried out according to the procedure given by ASTM D5731-08 (2008). The apparatus for this test consists of a rigid frame, two point load platens, a hydraulically activated 
ram with pressure gauge and a device for measuring the distance between the loading points. The test can be used to estimate other rock strength parameters. It was used to obtain the point load index $\left(I_{s(50)}\right)$ and tensile strength $\left(T_{0}\right)$ of rocks. It provides a basis for the mechanical classification of the rock as well as an estimate of the UCS of an intact rock (Karakus \& Tutmez 2006). The test provides rapid estimation of compressive and tensile strengths. Smith (1999), Bell (2007: 278-288) and Kohno \& Maeda (2011) recommended the use of point load strength index $\left(I_{s}\right)$ for rock strength testing. The reason is that $I_{s}$ can be determined in the field on specimens without preparation, using simple portable equipment (Williamson \& Kuhn 1988) and it can provide quick, reliable and practical values of UCS (Ghosh \& Srivastava 1991).

\section{PETROGRAPHIC ANALYSIS}

Petrographic preparation of rock slides was done in a standard way at the laboratory. The processes involve cutting the rock into small rectangular pellets of $3 \mathrm{~mm}$, mounted on glass slide using resin araldite. The mounted slide was lapped on a glass plate using medium-grained carborundum as an abrasive to generate friction between the rock pellet and the glass, in the process reducing the slide thickness to a desirable thickness of $0.3 \mathrm{~mm}$. At this thickness, it has been established that rocks behave like a transparent medium allowing the passage of light (Kerr 1977). Canada balsam was later used to seal the thinned rock using a glass cover lid. Hence, the study of the optical properties of mineral components of the rock was enhanced.

\section{OPTICAL STUDY}

Rock slides were studied under a microscope to determine the properties of the minerals which comprised the rocks. Usually, it is not necessary to analyze a mineral chemically to discover its identity (Murck 2001). Some properties are diagnostic features for some minerals. However, this approach may not be realistic when the minerals are aggregated to form rock. Additional studies like microscopic examination can shed more light on the identity of the mineral. This is the approach we adopted in this study. In general, physical and optical properties most often used to identify minerals are crystal form, habit, cleavage, hardness, luster, colour, streak, specific gravity (density), plaeochroism, extinction (angle), birefringence, interference colour and twinning. Optical observations were realized in both plane polarized and cross nicol light.

\section{RESULTS AND DISCUSSION}

All the data obtained were the mean values of the two results. The results of the physical characteristics of the rock aggregates are presented in Table 1 with the shape indices shown in Figure 3, while the strength characteristics of the rocks presented in Table 2 and Figure 4. The data of the strength indices obtained were subjected to statistical analysis; the mean and standard deviation (Tab. 3).

Table 1

Summary of the physical characteristics of aggregate samples

\begin{tabular}{|l|c|c|c|c|c|}
\hline $\begin{array}{c}\text { Sample } \\
\text { No. }\end{array}$ & Rock samples & $\begin{array}{c}\text { Elongation } \\
\text { index [\%] }\end{array}$ & $\begin{array}{c}\text { Flakiness } \\
\text { index [\%] }\end{array}$ & $\begin{array}{c}\text { Specific } \\
\text { gravity }\end{array}$ & $\begin{array}{c}\text { Water absorption } \\
\text { value [\%] }\end{array}$ \\
\hline GG1 & granite gneiss & 24.37 & 16.87 & 2.56 & 0.59 \\
\hline GG2 & granite gneiss & 24.65 & 18.53 & 2.54 & 0.61 \\
\hline GF & fine grained granite & 24.23 & 16.63 & 2.58 & 0.58 \\
\hline GC & porphyritic granite & 34.31 & 27.52 & 2.94 & 1.13 \\
\hline MG1 & migmatite gneiss & 31.27 & 26.04 & 2.63 & 0.92 \\
\hline MG2 & migmatite gneiss & 33.56 & 30.29 & 2.64 & 0.87 \\
\hline QZ1 & quartzite & 32.01 & 28.63 & 2.62 & 0.91 \\
\hline QZ2 & quartzite & 30.58 & 26.71 & 2.61 & 0.93 \\
\hline CK1 & charnockite & 25.01 & 20.06 & 2.54 & 0.61 \\
\hline CK2 & charnockite & 24.29 & 19.11 & 2.58 & 0.64 \\
\hline
\end{tabular}




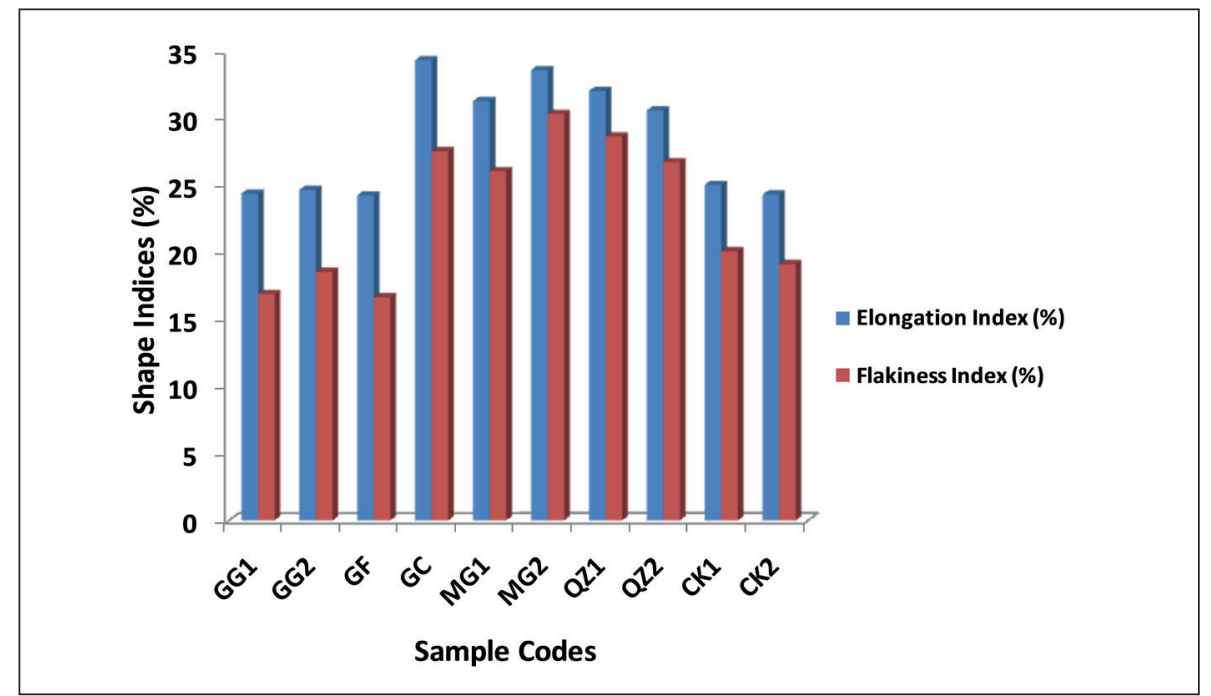

Fig. 3. Shape indices of the rock aggregates

Table 2

Strength test results of the rocks

\begin{tabular}{|l|c|c|c|c|c|c|c|}
\hline $\begin{array}{c}\text { Sample } \\
\text { No. }\end{array}$ & Rock samples & AIV [\%] & ACV [\%] & LAAV [\%] & $\begin{array}{c}I_{\text {s[50] }} \\
{[\mathbf{M P a}]}\end{array}$ & $\begin{array}{c}\text { UCS } \\
{[\mathbf{M P a}]}\end{array}$ & $T_{o}[\mathbf{M P a}]$ \\
\hline GG1 & granite gneiss & 19.26 & 21.12 & 26.41 & 16.94 & 179.63 & 19.83 \\
\hline GG2 & granite gneiss & 20.43 & 23.03 & 26.13 & 17.03 & 181.41 & 22.62 \\
\hline GF & fine grained granite & 15.63 & 18.32 & 25.22 & 17.21 & 187.46 & 22.47 \\
\hline GC & porphyritic granite & 19.84 & 23.83 & 27.48 & 16.56 & 159.12 & 19.39 \\
\hline MG1 & migmatite gneiss & 23.52 & 27.41 & 29.27 & 16.48 & 167.55 & 18.28 \\
\hline MG2 & migmatite gneiss & 21.17 & 28.93 & 31.06 & 16.73 & 171.80 & 19.54 \\
\hline QZ1 & quartzite & 14.79 & 19.57 & 34.55 & 10.19 & 167.47 & 14.31 \\
\hline QZ2 & quartzite & 18.62 & 21.15 & 32.71 & 11.26 & 163.65 & 17.06 \\
\hline CK1 & charnockite & 20.24 & 23.27 & 26.32 & 16.81 & 179.44 & 21.88 \\
\hline CK2 & charnockite & 22.11 & 22.13 & 26.04 & 16.94 & 173.62 & 20.23 \\
\hline
\end{tabular}

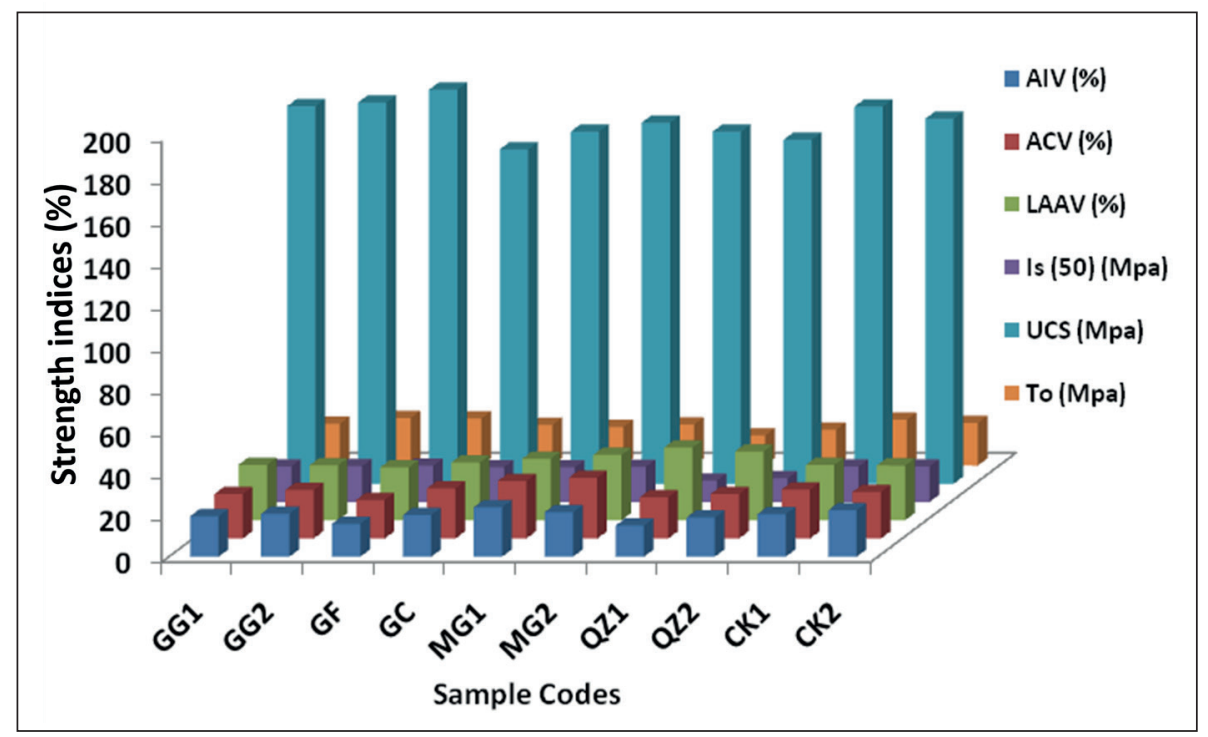

Fig. 4. Strength indices of the rock aggregates 
Table 3

Statistical description of strength indices of the rock aggregates

\begin{tabular}{|l|c|c|c|c|c|c|}
\hline \multirow{2}{*}{ Sample No. } & \multicolumn{7}{|c|}{${\text { Mean } \pm \text { SD }^{\mathbf{a}}}$} \\
\cline { 2 - 7 } & AIV [\%] & ACV $[\%]$ & LAAV $[\%]$ & $I_{s(50)}[\mathrm{MPa}]$ & UCS $[\mathbf{M P a}]$ & $T_{o}[\mathrm{MPa}]$ \\
\hline GG1 & $19.26 \pm 0.06$ & $21.12 \pm 0.03$ & $26.41 \pm 0.03$ & $16.94 \pm 0.03$ & $179.63 \pm 0.10$ & $19.83 \pm 0.03$ \\
\hline GG2 & $20.43 \pm 0.06$ & $23.03 \pm 0.23$ & $26.13 \pm 0.03$ & $17.03 \pm 0.35$ & $181.41 \pm 0.03$ & $22.62 \pm 0.89$ \\
\hline GF & $15.63 \pm 0.31$ & $18.32 \pm 0.03$ & $25.22 \pm 0.08$ & $17.21 \pm 0.01$ & $187.46 \pm 1.24$ & $22.47 \pm 0.07$ \\
\hline GC & $19.84 \pm 0.14$ & $23.83 \pm 0.55$ & $27.48 \pm 0.06$ & $16.56 \pm 0.17$ & $159.12 \pm 1.03$ & $19.39 \pm 0.59$ \\
\hline MG1 & $23.52 \pm 0.04$ & $27.41 \pm 0.40$ & $29.27 \pm 0.01$ & $16.48 \pm 0.13$ & $167.55 \pm 3.65$ & $18.28 \pm 0.03$ \\
\hline MG2 & $21.17 \pm 0.09$ & $28.93 \pm 0.18$ & $31.06 \pm 0.07$ & $16.73 \pm 0.10$ & $171.80 \pm 1.94$ & $19.54 \pm 0.28$ \\
\hline QZ1 & $14.79 \pm 0.03$ & $19.57 \pm 0.13$ & $34.55 \pm 0.03$ & $10.19 \pm 0.11$ & $167.47 \pm 0.03$ & $14.31 \pm 0.06$ \\
\hline QZ2 & $18.62 \pm 0.03$ & $21.15 \pm 0.06$ & $32.71 \pm 0.03$ & $11.26 \pm 0.04$ & $163.65 \pm 0.03$ & $17.06 \pm 0.40$ \\
\hline CK1 & $20.24 \pm 0.37$ & $23.27 \pm 0.10$ & $26.32 \pm 0.01$ & $16.81 \pm 0.10$ & $179.44 \pm 2.22$ & $21.88 \pm 0.10$ \\
\hline CK2 & $22.11 \pm 0.11$ & $22.13 \pm 0.06$ & $26.04 \pm 0.18$ & $16.94 \pm 0.10$ & $173.62 \pm 1.37$ & $20.23 \pm 0.17$ \\
\hline
\end{tabular}

$\mathrm{SD}-$ standard deviation, $\mathrm{a}-$ number of tests $=2$.

\section{Particle shape}

The shape of aggregate particles is a product of the rock type, depositional environment, quarrying and production process. Flakiness and elongation are measures of poor particle shape. The flakiness of the sample aggregates ranges from $16.63 \%$ to $30.29 \%$, and the elongation ranges from $24.23 \%$ to $34.31 \%$ (Tab. 1). Flaky and elongated aggregates are detrimental to the workability and stability of mixes because flat, flaky or long, thin particles will not interlock well and result in weak road stone or concrete products. Thus, a limit of $35 \%$ flaky particles is imposed for a general purpose construction aggregate whereas a maximum permitted 25\% flaky particles is imposed for wearing course road stone (BS 812 105.1, 1989). Shape indices measurements show that the aggregate of the samples from fine to medium grained granite (GF) is the most suitable for construction because of its lowest values of elongation index and flakiness index, followed by samples from granite gneiss and charnockite (Fig. 3). The flakiness indices of GC, MG1, MG2, QZ1 and QZ2 are above the specified limit of $25 \%$ recommended by BS 812105.1 (1989). Also, the elongation indices of all the samples are above the specified limit of less than 25\% of BS 812105.2 (1990) except the aggregates of the samples from GF, GG1, GG2 and CK2 (Tab. 1).

\section{Water absorption of rocks}

The water absorption values range from $0.68 \%$ to $1.13 \%$ (Tab. 1). The water absorption values are within the acceptable limits of less than 3\% for highway pavement aggregates (BS 882, 1992). It was observed that porphyritic granite has the highest water absorption value of all the rocks due to its bigger particle size. According to the specification of BS 812-2 (1995), the water absorption value should be less than $3 \%$ for overall uses of aggregates but ASTM C127 (2001) specified that it should be less than $2 \%$. The analysed samples of aggregate are all below $2 \%$, indicating low effective porosity. This relatively low value of water absorption suggests the suitability of these aggregates in civil engineering construction works. All the samples analysed have a water absorption of less than $1 \%$, which implies that they are strong aggregates for most construction work and can be considered suitable for use as foundation materials, even in water logged areas, with the exception of porphyritic granite rock aggregates (GC) which have a water absorption $>1 \%$.

\section{Specific gravity}

The specific gravity of all the rock aggregates range between 2.54 to 2.94 (Tab. 1). The higher specific gravity is due to the low degree of weathering and compact nature of the rocks. Except for 
the aggregate samples from porphyritic granite (BS: specific gravity generally less than 2.65 for roadstone). The rock aggregates are generally considered suitable for road construction.

\section{Aggregate strength characteristics}

The aggregate strength characteristics are used to evaluate the suitability of aggregate for use in road stone or concrete.

\section{Aggregate impact value (AIV)}

The impact value of aggregates measures the toughness of particles by impact as aggregates to be used in construction. They should be tough enough to resist friction from such impact and the AIV of aggregate samples ranges from $14.79 \%$ to $23.52 \%$ (Tab. 2). The AIV of the aggregate samples ranges from "strong" to "good" for road surfacing when compared with Singh 1991 classification because the lower the AIV the stronger the aggregate. These values fall within the BS 8821992 recommended value of a maximum of $30 \%$.

\section{Aggregate crushing value (ACV)}

The aggregate crushing value is a measure of the resistance of the aggregates to crushing under a gradually applied compressive load. ACV of the samples ranges from $18.32 \%$ to $28.93 \%$ (Fig. 4). The values fall within the recommended value of maximum of $30 \%$ (BS 882, 1992), thus, it can be used for heavy-duty concrete floor finishes, for concrete pavement wearing surfaces and in other building concretes. The higher the value of ACV, the weaker are the aggregates in construction. An $\mathrm{ACV}$ greater than $35 \%$ indicates that the aggregate is too weak for most construction uses (Mitchell 2007). Materials with low aggregate crushing values are generally preferred for use in highway pavements.

\section{Los Angeles abrasion value (LAAV)}

LAAV is a measure of the resistance of the aggregates to surface wear by abrasion (the lower the value, the greater the resistance). It is the preferred method to evaluate aggregates and it ranges from $25.22 \%$ to $34.55 \%$ (Tab. 2). Rock materials with aggregate abrasion values below $30 \%$ are regarded as strong and can be used for bituminous mixes while those above $35 \%$ would normally be regarded as too weak for use in road surfaces. Therefore, some of the aggregates (GG1, GG2, GF, GC, MG1, CK1 and CK2) are suitable for bituminous mixes and all the rock materials are suitable for base courses since a LAAV below $50 \%$ can be used for these and less than 16\% for Portland cement concrete (PCC) (ASTM C131-01, 2001). This implies that the aggregate samples possess good qualities for use as roadstones because of their lower LAAV which would make them more resistant to wear. They are therefore recommended for use as aggregates for highway pavement constructions.

\section{Unconfined compressive strength (UCS) test}

The UCS test is certainly the most reliable method to determine the compressive strength of rocks (Liang et al. 2015). The highest value of UCS was observed in sample GF (187.46 MPa) and the lowest value of compressive strength was noted in sample GC (159.12 MPa) (Fig. 4). UCS of the rock samples of the area fall into the "very strong" category, when compared with ISO (2003) classification. This suggests that the rock aggregates are appropriate for concrete and road aggregates. Porphyritic granite stands out with a lower UCS of all the rock types, although it is classified as a very strong rock material for construction.

\section{Point load strength test (PLST, $I_{s(50)}$ )}

Point load strength index values vary from $10.19 \mathrm{MPa}$ of quartzite sample from Qz1 and 17.21 MPa of fine grained granite. The values of tensile strength range from 14.31 MPa to a maximum of $22.62 \mathrm{MPa}$ (Fig. 4). These higher $\left(I_{s(50)}\right.$ and $\left.T_{o}\right)$ strength values of all the rock samples higher than the findings of Liang et al. (2015) and Singh et al. (2012) is the reason for their sound petrographic character and higher strength values.

\section{Petrographic studies}

An optical study of the thin sections prepared from five rock samples collected revealed the mineral assemblages of these rocks. Mineralogical contents of the rock samples show quartz, biotite, muscovite, feldspars, hornblende and other opaque minerals in various percentages as depicted in Table 4. 
Table 4

Average modal composition of rocks from the study area

\begin{tabular}{|c|c|c|c|c|c|}
\hline Mineral & Granite gneiss & Granite & $\begin{array}{c}\text { Migmatite } \\
\text { gneiss }\end{array}$ & Quartzite & Charnockite \\
\hline Quartz & 30 & 35 & 27 & 85 & 10 \\
\hline K-feldspar & 35 & 30 & 20 & - & 8 \\
\hline Plagioclase & 20 & 18 & 22 & - & 22 \\
\hline Biotite & 5 & 8 & 11 & 6 & 10 \\
\hline Microcline & - & - & - & - & - \\
\hline Hornblende & 4 & - & 6 & - & 25 \\
\hline Muscovite & 4 & 6 & 6 & 6 & 6 \\
\hline Hypersthene & - & - & - & - & 15 \\
\hline Garnet & - & - & 6 & - & - \\
\hline Opaque minerals & 2 & 3 & 2 & - & 3 \\
\hline
\end{tabular}

Based on field observation of the area of study, it consists of mixed suite of metamorphic rocks and igneous rocks. The identified lithological units predominantly comprise migmatite gneiss, charnokitic rocks and granite (Fig. 2). Migmatite gneiss are dominant in the study area, occurring as ridges and hills which contain quartz veins, dykes, quartzo-feldspathic intrusion and pegmatitic veins usually very extensive. Petrographic studies revealed quartz, potassium feldspar, plagioclase, biotite, muscovite, garnet and opaque minerals as the major minerals (Tab. 4). The migmatite gneiss of the study area, although classified as a very strong rock material for concrete and road aggregates (Tabs. 2, 3), has limitations in terms of its use in certain conditions due to its weathered nature in some parts of the area. Rocks with a higher weathering degree have a lower UCS value, since the number of pores and cracks increases the deformability, while the strength decreases (Tugrul 2004, Rigopoulos et al. 2010).

The granite forms the basement lithology in some other parts of the area. These rocks are generally trending in N-S direction typical of the basement complex rocks. Structural features such as faults, joints, xenoliths, folds, dykes etc. characterize the rocks. Granite is formed from silicate melts, in which the silica content is greater than $65 \%$. It is entirely crystalline with grain boundaries interlocked and there is no plane of weakness in the rock mass. The high strength characteristics of granite, especially fine grained granite and its low water absorption value, could be ascribed to the intrusive igneous rock of granite with the major mineralogical composition of quartz $\left(\mathrm{SiO}_{2}\right)$, feldspar, biotite and muscovite (Tab. 4).

The charnockitic rocks in the area of study are massive, greenish, with a characteristic oval to circular shape within the migmatite gneiss complex, distinct individual bodies in the gneiss complex and occur along margins of older granites especially biotite and biotite hornblende granites. The charnockites are fresh outcrops with little signs of weathering. On the outcrops, the occurrences of pegmatite, aplite and quartz veins as minor intrusions can be found. Petrographic studies revealed quartz, biotite, hornblende, muscovite, plagioclase, hypersthenes and opaque minerals as the major mineralogical contents of the rocks (Tab. 4).

Granite gneiss is widely distributed throughout the area. It occurs mostly as hills, boulders and flat lying exposures. They are dark grey to light grey. They consist of several quartzite intrusions cutting across the granite. Mineralogically, granite gneiss consists of quartz, biotite, and feldspar (Tab. 4) with some traces of garnet which is coarse grained. The minerals are randomly oriented. The exposure has a quartz vein and pegmatite intrusion with different grain sizes. Granite gneiss consists of a linear fabric with some planar fabric and also consists of alternating light and dark bands. Granite gneiss in the area of study is mainly biotite rich gneiss and banded gneiss. The biotite rich gneiss is fine to medium grained that show strong foliation trending westwards and is usually dark in colour. The banded gneiss shows a parallel alignment and alteration. Gneiss is a high grade regional metamorphic 
rock formed from either sedimentary or igneous rocks. It has a foliated texture of light and dark bands; the light bands are quartz and feldspars, while, the dark bands are biotite, amphibole and magnetite. The parallel layers produce a banded structure which acts as a plane of weakness in the rock mass. The folded structures in the rock are also an indication of the stresses it had undergone in the past. Although the granite gneiss showed a similar mineralogical composition (quartz, feldspar and ferromagnesian minerals like biotite and hornblende) (Tab. 4), it gave lower strength properties compared with granite. The mineralogical composition of the quartzite comprises quartz, biotite and muscovite (Tab. 4).

\section{CONCLUSIONS}

Rocks, just like soils, fail when they are subjected to loads above their strength. Hence, it is important to have a good knowledge and understanding about the engineering properties and mineralogical composition of rocks and rock aggregates, which in-turn determines their behavior when they are used in construction. This is essential to ensure their suitability as construction aggregates in order to meet the demands of the end-users for stability and durability of engineering structures. Results of shape indices measurements show that the aggregates of the samples from GF, GG1, GG2 and CK2 are more suitable for construction because of their low flakiness (FI) and elongation (EI) indices. All the samples analyzed are considered strong aggregates suitable as foundation materials even in water logged areas, with the exception of porphyritic granite rock aggregates (GC) with a water absorption $>1 \%$. Aggregates produced from the rock deposits satisfy all the requirements (strength characteristics) and suggest that they are very strong for structural concrete, are suitable for bituminous mixes, and represent quality and stable highway pavement aggregates when compared with the existing standards. Mineralogical contents of the rock samples show quartz, biotite, muscovite, feldspars, hornblende and other opaque minerals in various percentages. Among all the rocks analysed, aggregates produced from fine grained granite, granite gneiss and charnockite were found to be the most efficient for civil constructions, because of the lower FI, EI, water absorption, and higher strength properties possessed by the rocks. These properties of the aggregates guarantee the stability and long life expectancy of engineering structures constructed with them. This study will serve as baseline information to help and guide the construction industries to select the best rock types for construction and concrete design. This is necessary to meet the demand of end-users for quality construction aggregates in order to prevent incessant structural failure. It is recommended that rocks should be tested before their use in construction. Also, priority must be placed on the selection of the right type of aggregates globally for their accurate applications in civil engineering construction work.

\section{REFERENCES}

AASHTO, 2001. Specific gravity and absorption of coarse aggregate. Technical Specification No. T85, Washington DC.

AASHTO M-132, 1987. Standard specification for terms relating to density and specific gravity of solids, liquids and gases. The American Association of State Highway and Transportation Officials.

Ajibade A.C. \& Fitches W.R., 1988. The Nigerian Precambrian and the Pan-African Orogeny. [in:] Oluyide P.O., Mbonu W.C., Ogezi A.E.O., Egbuniwe I.G., Ajibade A.C. \& Umeji A.C. (eds.), Precambrian Geology of Nigeria, Geological Survey of Nigeria, 45-53.

ASTM C127-01, 2001. Standard test method for density, relative density (specific density) and absorption of fine aggregate. ASTM International, West Conshohocken, PA.

ASTM C131-01, 2001. Standard test method for resistance to degradation of small-size coarse aggregate by abrasion and impact in the Los Angeles Machine. ASTM International, West Conshohocken, PA.

ASTM C170, 2001. Standard test method for compressive strength of dimension stone, ASTM International.

ASTM D5731-02, 2008. Standard test method for determination of the point load strength index of rock and application to rock strength classifications. American Society for Testing and Materials, Pennsylvania, USA.

Bell F.G., 2007. Engineering Geology. $2^{\text {nd }}$ ed. Elsevier.

BGS, 2013. Construction aggregates: Mineral Planning Factsheet. British Geological Survey.

BS 812 105.1, 1989. Testing aggregates. Methods for determination of particle shape. Flakiness index. British Standard Institution, London..

BS 812 105.2, 1990. Testing aggregates. Methods for determination of particle shape. Elongation index. British Standard Institution, London.

BS 882, 1992. Specifications for aggregates from natural sources for concrete and roadstones. British Standard Institution, London. 
BS 812, Part 2, 1995. Methods for sampling and testing of mineral aggregates, sand and fillers. British Standard Institution, London.

Dhir R.K. \& Jackson N., 1980. Concrete. [in:] Jackson N. (ed.), Civil Engineering Materials, Macmillan Press, London, 107-202.

Egesi N. \& Tse C.A., 2012. Engineering-Geological evaluation of rock materials from Bansara, Bamenda Massif Southeastern Nigeria, as aggregates for pavement construction. Geosciences, 2(5), 107-111.

Eren O. \& Bahali M., 2005. Some engineering properties of natural building cut stones of Cyprus. Construction Building Materials, 19, 213-222.

Fowler D.W. \& Quiroga P.N., 2003. The effects of aggregate characteristics on the performance of Portland cement concrete. ICAR 104-IF, No. 382, International Centre for Aggregate Research.

Franklin B.J. \& Young Y., 2000. The modulus of rupture test and its significance for durability for Building stone, Sandstone city, Sidney's Building stone and other sandstone geomaterials. [in:] Skilbeck C.G. \& Hubble T.C.T. (eds.), Searching for a sustainable future 15th Australian Geological Convention, Sydney, July 3rd-7th, 2000, University of Technology, Sydney, Abstracts - Geological Society of Australia, 59, Geological Society of Australia, Sydney, 223-226.

Ghosh D.K. \& Srivastava M., 1991. Point load strength: an index for classification of rock material. Bulletin of International Association of Engineering Geology, 44, 1, 27-33.

ISO 14689-1:2003, Geotechnical investigation and testing. Identification and classification of rock, Part 1: identification and description. International Organization for Standardization, Geneva.

Jackson N., 1984. Civil Engineering Materials. $2^{\text {nd }}$ ed. Macmillan Press, London.

Kadiyali L.R., 1989. Principles and Practice of Highway Engineering. Khanna Publishers, New Delhi.

Karakus M. \& Tutmez B., 2006. Fuzzy and multiple regression modeling for evaluation of intact rock strength based on point load, Schmidt hammer and sonic velocity. Rock Mechanics and Rock Engineering, 39, 1, 45-57.

Kerr P.F., 1977. Optical Mineralogy. $4^{\text {th }}$ ed. McGraw-Hill.

Kohno M. \& Maeda H., 2011. Estimate of uniaxial compressive strength of hydrothermally altered rocks from northeastern Hokkaido, Japan, based on axial point load strength test results. International Journal of JCRM, 7, 1, $17-23$.

Liang M., Tonnizam E., Khun M.C. \& Alel M.N.A., 2015. Estimating uniaxial compressive strength of tropically weathered sedimentary rock using indirect test. Jurnal Teknologi, 72, 3, 49-58.

Mitchell C., 2007. GoodQuarry Production Technology. [on-line:] http://nora.nerc.ac.uk/15899/1/GoodQuarry_ Production_Technology.pdf.

Murck B.W., 2001. Geology: A Self-teaching Guide Wiley self-teaching guides. John Wiley and Sons.

Olarewaju V.O., 1981. Geochemistry of the charnockitic and granitic rocks of the basement complex around Ado-Ekiti - Akure, Southwestern Nigeria. University of London [unpublished Ph.D. thesis].
Olorunfemi M.O., Ojo J.S. \& Akintunde O.M., 1999. Hydrogeophysical evaluation of the groundwater potential of the Akure metropolis, Southwestern Nigeria. Journal of Mining and Geology, 35, 2, 207-228.

Oyinloye A.O., 2011. Geology and Geotectonic Setting of the Basement Complex Rocks in Southwestern Nigeria: Implications on Provenance and Evolution. Earth and Environmental Sciences, 98-117.

Rahaman M.A., 1981. Recent Advances in the Study of the Basement Complex of Nigeria. [in:] The Precambrian Geology of Nigeria: (Proceedings of the First Symposium on the Precambrian Geology of Nigeria Organised by the Geological Survey of Nigeria, Under the Auspicies of the Federal Ministry of Mines and Power, from 14th to 17th October 1981 at Durbar Hotel, Kaduna, Geological Survey of Nigeria, 11-43.

Rahaman M.A., Emofurieta W.O. \& Cean-Vachette M., 1983. The potassic granite of Igbetti area. Further evidence of the polycyclic evolution of the Pan-African belt in Southwestern Nigeria. Journal of Precambrian Resources, 22, 75-92.

Rigopoulos I., Tsikouras B., Panagiotis Pomonis P. \& Hatzipanagiotou K., 2010. The influence of alteration on the engineering properties of dolerites: the examples from the Pindos and Vourinos ophiolites (northern Greece). International Journal of Rock Mechanics and Mining Science, 47, 69-80.

Siegesmund S. \& Torok A., 2011. Building stones. [in:] Siegesmund S. \& Snethlage R. (eds.), Stone in Architecture-Properties, Durability, $4^{\text {th }}$ ed., Springer, Berlin, 11-96.

Singh G.C., 1991. Highway Engineering. Standard Publishers Distributors, India.

Singh T.N., Kainthola A. \& Venkatesh A., 2012. Correlation between point load index and uniaxial compressive strength for different rock types. Rock Mechanics and Rock Engineering, 45, 259-264.

Smith M.R., 1999. Stone: Building Stone, Rock Fill and Armourstone in Construction. Geological Society of London, London.

Smith M.R. \& Collis L., 1993. Aggregates: Sand, Gravel and Crushed Rock Aggregate for Construction Purposes. Geological Society, London.

Sousa L.M.O., 2012. The influence of the characteristics of the quartz and mineral deterioration on the strength of granitic dimensional stones. Environmental and Earth Sciences, 69, 4, 1333-1346.

Tugrul A., 2004. The effect of weathering on pore geometry and compressive strength of selected rock types from Turkey. Engineering Geology, 75, 215-227.

Vallejo L.G.D. \& Ferrer M., 2011. Geological Engineering. CRC Press.

Williamson D.A. \& Kuhn C.R., 1988. The unified classification system. [in:] Kirkaldie L. (ed.), Rock classification systems for engineering purposes, ASTM Special Technical Publication, 984, American Society for Testing Materials, Philadelphia, 7-16.

Zorlu K., Gokceoglu C., Ocakoglu F., Nefeslioglu H.A. \& Acikalin S., 2008. Prediction of uniaxial compressive strength of sandstone using petrography-based models. Engineering Geology, 96(3-4), 141-158. 